\title{
Low doses of gamma radiation in the management of postharvest Lasiodiplodia theobromae in mangos
}

\author{
Alice Maria Gonçalves Santos ${ }^{1}$, Severina Rodrigues Oliveira Lins ${ }^{1}$, \\ Josenilda Maria da Silva ${ }^{2}$, Sônia Maria Alves de Oliveira ${ }^{1}$ \\ ${ }^{1}$ Seção de Fitopatologia, Universidade Federal Rural de Pernambuco, Recife, PE, Brazil. \\ ${ }^{2}$ Centro Regional de Ciências Nucleares, Recife, PE, Brazil.
}

Submitted: April 30, 2014; Approved: February 16, 2015.

\begin{abstract}
The postharvest life of mango is limited by the development of pathogens, especially fungi that cause rot, among which stands out the Lasiodiplodia theobromae. Several control methods have been employed to minimize the damages caused by this fungus, chemical control can leave residues to man and nature; physical control by the use of gamma radiation in combination with modified atmosphere and cold storage. The use of gamma radiation helps to reduce the severity of the pathogen assist in the ripening process of fruits, even at low doses $(0.25,0.35$ and $0.45 \mathrm{kGy})$ chemical properties such as $\mathrm{pH}$, soluble solids, acid ascorbic, titratable acidity and also the quality parameters of the pulp showed no damage that are ideal for trade and consumption of mangoes. This treatment can be extended for use in the management of diseases such as natural infections for penducular rot complex that has as one of $L$. theobroma pathogens involved.
\end{abstract}

Key words: Mangifera indica, ionizing radiation, quality.

\section{Introduction}

A survey of irrigated fruit farming in the semi-arid region of northeastern Brazil reveals that the pathogen Lasiodiplodia theobromae (Pat.) Griffon and Maubl accounts for major plant health problems in São Francisco Valley. The high degree of disease severity is due to climatic conditions that are favorable to the development of this fungus, with little variation throughout the year (Tavares et al., 1991). Based on scientific data, it is believed that the pathogenicity of $L$. theobromae increased as a result of environmental pressure, particularly in the region in question (Tavares, 2002). Moreover, the susceptibility of the mangos to the rot increases after harvest and storage as a result of physiological changes in fruit, disqualifying them for marketing due to involvement of the peel and pulp (Tavares et al., 1991).

The postharvest life of mango is limited by the rapid ripening of fruits and the development of pathogens causing rot (Almeida et al., 2005). However, this conservation can be extended with the use of refrigeration and modified atmosphere (Jerônimo and Kanesiro, 2000).

The recommended temperature for mangos is approximately $12^{\circ} \mathrm{C}$ (Alves et al., 1998). According to Calore and Vieites (2003), the use of a low storage temperature in combination with a modified atmosphere can slow the development of any microorganisms that may be present. Adequate postharvest handling in combination with food preservation methods should be employed to prolong the shelf life of fruits and vegetables, thereby extending the commercialization period (Jerônimo and Kanesiro, 2000).

Advances in technological processes of food preservation over the last 50 years show that the gamma radiation of cobalt 60 and cesium 137 or even accelerated electrons is capable of inhibiting the proliferation of microorganisms (Kaferstein and Moy, 1993). According to Chitarra and Chitarra (2005), the irradiation of fruits and vegetables postharvest's has a main interest in the reduction or delay the damage caused by disease, presenting antifungal effect. However, it is also used as a preservation method, by prolonging the storage by delayed ripening and sprouting of

Send correspondence to A. Santos. Seção de Fitopatologia, Universidade Federal Rural de Pernambuco, Rua Dom Manuel de Medeiros, 52171-900 Recife, PE, Brazil. E-mail: alicemgsantos@yahoo.com.br. 
some products. However, its use has some disadvantages, such as browning, softening, the appearance of surface depressions, abnormal maturation and loss of aroma and flavor of the products (Nagajata, 2007). The nature and extent of these changes depends on the type, composition and variety of the fruit, as well as the radiation dose applied and the environmental conditions during and after the radiation process.

The application of ionizing radiation may alter the structural components of some fruits, giving them a better appearance and enhancing their firmness. Low doses of radiation can lead to the hydrolysis of some components, resulting in a longer shelf life and the conversion from starch to sugar (Lima et al., 2001). Irradiated fruits are often sweeter than non-irradiated ones (Thomas, 1986). During the ripening of mangos, the contents of organic acid diminishes and the soluble sugar increases, resulting in a predominance of sweetness in the ripe fruit (Bernardes-Silva et al., 2003). Monitoring these changes serves as a basis to evaluate if the ionizing radiation committed the ripening of fruits.

This study aimed to evaluate the effect of gamma radiation $(0.25,0.35$ and $0.45 \mathrm{kGy})$ associated with modified atmosphere in controlling of rot caused by L. theobromae and its impact on shelf life and the physicochemical characteristics of fruits.

\section{Materials and Methods}

The experiment was conducted at the Postharvest Pathology Laboratory at UFRPE and at the Department of Nuclear Energy of the Universidade Federal de Pernambuco (Brazil) in cooperation with the Postharvest of Fruit Laboratory of the Centro Regional de Ciências Nucleares (Brazil).

\section{Pathogen}

The phytopathogenic fungus used in the present study was obtained from the collection of the Empresa Brasileira de Pesquisa Agropecuária - Embrapa Semiárido (Brazil). The isolate was cultured on potato - dextrose - agar (PDA) and, inoculated into healthy fruits.

\section{Effects of gamma radiation on development of $L$. theobromae in mango}

Tommy Atkins mangos picked at mature-green or at maturity stages 2 and 3 (Deutsche Gesellschaft für Technische Zusammenarbeit - GTZ (1992)) from an orchard in Petrolina (Pernambuco State, Brazil) were immediately and carefully transported to the laboratory, where they were selected, washed and dried at $26 \pm 2{ }^{\circ} \mathrm{C}$, relative humidity (RH) of $70 \pm 5 \%$. After that, fruits were wounded with a sterilized perforator ( 8 needles, $5 \mathrm{~mm}$ in diameter and $2 \mathrm{~mm}$ deep) and on each wound, was deposited $10 \mu \mathrm{L}$ with of a $L$. theobromae spore suspension at a concentration of $10^{6}$ conidia $\mathrm{mL}^{-1}$. The Control were injured by the same way, but inoculum was switched for $10 \mu \mathrm{L}$ of sterilized distilled water.

Mangoes were packed in pairs, in expanded polystyrene trays $(15 \mathrm{~cm} \mathrm{x} 10 \mathrm{~cm})$ coated whit PVC film and maintained at $26 \pm 2{ }^{\circ} \mathrm{C}$. The trays were maintained in the laboratory conditions $\left(26 \pm 2{ }^{\circ} \mathrm{C} ; 70 \pm 5 \% \mathrm{RH}\right)$ for $24 \mathrm{~h}$ and $70 \pm$ $5 \% \mathrm{RH}$ for another $24 \mathrm{~h}$. After this period, the trays containing the mango were treated whit radiation doses previously predetermined $(0.25,0.35$ and $0.45 \mathrm{kGy})$ using a Gammacell $^{\circledR} 220$ Excel radiator (MDS Nordion, Canada), whose rate at time of application was cobalt60 source and $7.303 \mathrm{kGy} / \mathrm{h}$. The positive control was composed of mangos inoculated with the phytopathogen but not irradiated and the negative control was composed of mangoes without inoculation or irradiation. After the application doses, irradiated and non-irradiated trays were kept under cold storage at $13{ }^{\circ} \mathrm{C}$ for 15 days and then transferred to the incubation room $\left(26 \pm 2{ }^{\circ} \mathrm{C}\right.$ and $\left.70 \% \mathrm{RH}\right)$ without the PVC for 6 days.

The experiment was conducted with an entirely randomized design consisting of 4 treatments and 4 replicates, with each replicate containing 5 mangos. The same design was used for evaluation of the physicochemical characteristics.

The evaluation of disease severity consisted of the measurement of the diameter of the lesion using a caliper rule (Mitutoyo, Kaeasaki, Japão) first after the trays were removed from the cold chamber and every 2 days until the degeneration of the fruit occurred 6 days after leaving the cold chamber. The data were subjected to analysis of variance and regression analysis, the model was defined by the coefficient of determination, using the SAS Software (SAS Institute, 2000).

\section{Evaluation of physicochemical characteristics}

The fruits were evaluated at four different times: at the entrance of the cold chamber (Day 1); 15 days after the cold storage or at the end of the cold storage (Day 15), two days after leaving the cold chamber (Day 17); and four days after leaving the cold chamber (Day 19). The characteristics evaluated were: pulp firmness, pulp color, hydrogen potential $(\mathrm{pH})$, solid soluble (SS), titratable acidity (TA), ascorbic acid (Vitamin C) and maturation index (MI) determined by SS/TA ratio.

Pulp firmness was determined on opposite peeled sides of the fruit using a penetrometer model FT 327 (0-13 Lbs.) (Wagner Instruments, Greenwich, London) and the results were expressed in kgf. This analysis was performed at the end of the cold storage and at two and four days after leaving the cold chamber (Day 17 and Day 19).

The pulp color was determined using a Minolta CR300 colorimeter with three readings in different parts of the pulp of each fruit. The results were expressed in $\mathrm{L}^{*}, \mathrm{a}^{*}$ and $b^{*}$. L* values range from 0 (white) to 100 (black), represent the brightness of the pulp; a* values indicate chromaticity 
ranging from green (-) to red $(+)$; and $\mathrm{b}^{*}$ values indicate chromaticity ranging from blue (-) to yellow (+).

The chemical characteristics were determined after the disintegration of the pulp, domestic centrifuge. The $\mathrm{pH}$ was checked at $10 \mathrm{~g}$ of pulp in potentiometer Quimis Model 400A. The levels of ascorbic acid in pulp were determined according to the method described by Carvalho et al. (1990) The solid soluble contents (SS) were quantified by direct reading on refractometer, Model Rez $\left(0-32^{\circ}\right.$ Brix $)$, and the results expressed in ${ }^{\circ}$ Brix, while the titratable acidity (TA) was determined according to the methodology described by Ohlweiler (1980). The maturation index (MI) was also determined by SS/TA ratio. In all of these analyzes were utilized three replicates for each fruit.

The data were subjected to analysis of variance and regression analysis, the model was defined by the coefficient of determination, using the SAS Software (SAS Institute, 2000). Graphs were plotted using Sigma Plot (2008). Firmness data were analyzed using Tukey's test, with the level of significance set to $5 \%(\mathrm{p}<0.05)$, using the SAS Software (SAS Institute, 2000).

\section{Results and Discussion}

\section{Effects of gamma radiation on development of $L$. theobromae in mango}

The doses of radiation used and the presence of PVC film during the cold storage of mangos did not cause the appearance of peel spots or caused other changes in fruits, differently the results reported by Calore and Vieites (2003) in peaches treated with $0.5 \mathrm{kGy}$ and by Pfaffenbach et al. (2003) in mangoes packed in plastic film and kept under re- frigeration. In the first evaluation of the effects of radiation on rot development by L. theobromae made at the end of the cold storage it was observed that fruits had no symptoms of decay resulting from inoculation with the pathogen. In the second evaluation held two days after leaving the cold chamber it was checked disease incidence in all treatments, with significant differences in severity. Fruits treated with the lowest dose $(0.25 \mathrm{kGy})$ showed similar disease development to Control (Figure 1).

However, the highest dose $(0.45 \mathrm{kGy})$ resulted in the greatest reduction in disease development. According to Morais et al. (2003) the cold storage slows the ripening of fruits, providing longer shelf-life beyond make feasible their exportation. The quality of the mangoes after their removal from the cold chamber is extremely important for the successful of the conservation process (Neves et al., 2002). The association between gamma irradiation and modified atmosphere may contribute to the maintenance of fruit quality as observed in this study.

\section{Evaluation of physicochemical characteristics}

The results of this study demonstrate that gamma radiation associated with cold storage reduces loss firmness mangos that received the highest dose $(0.45 \mathrm{kGy})$ had the best values of firmness (Table 1) at all stages of evaluation. A loss of firmness hampers the commercialization of fruits and this factor can be attenuated by proper handling and preservation methods (Lima et al., 2009). The dose $0.45 \mathrm{kGy}$, was effective in preserving the firmness of the mangoes. These findings are similar to those reported by Miller and McDonald (1999), who found a positive interac-

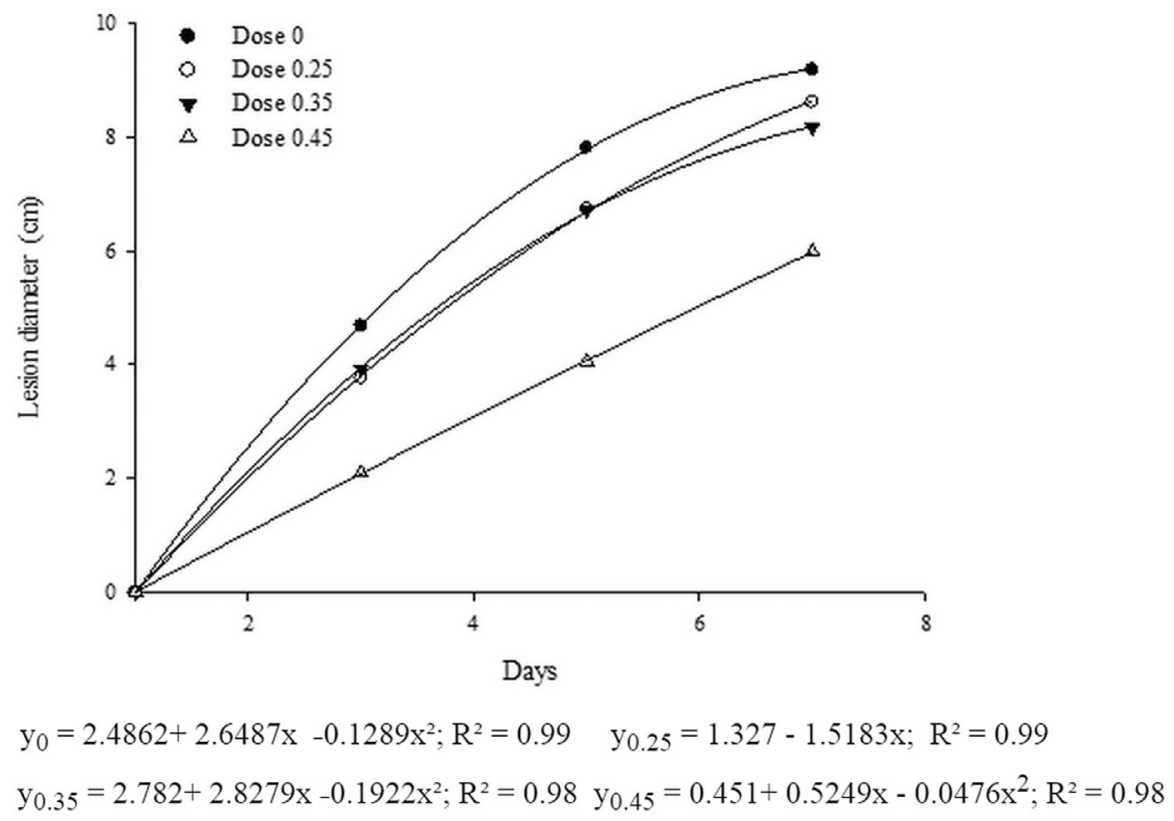

Figure 1 - Development of stem-end rot on Tommy Atkins mangos inoculated with L. theobromae and irradiated with gamma radiation at doses of 0 , $0.25,0.35$, and $0.45 \mathrm{kGy}$ followed by refrigerated storage with a PVC wrap at $13{ }^{\circ} \mathrm{C}$ and storage without a PVC wrap at $26{ }^{\circ} \mathrm{C}$ with $90 \% \mathrm{RH}$. 
Table 1 - Pulp firmness (kgf) of Tommy Atkins mangos inoculated with L. theobromae and irradiated with doses of $0,0.25,0.35$, and $0.45 \mathrm{kGy}$, followed by refrigerated storage with a PVC wrap at $13{ }^{\circ} \mathrm{C}$ and storage without a PVC wrap at $26^{\circ} \mathrm{C}$ with $90 \% \mathrm{RH}$.

\begin{tabular}{lcccc}
\hline \multirow{2}{*}{ Days } & \multicolumn{4}{c}{ Dose of gamma radiation (kGy) } \\
\cline { 2 - 5 } & 0 & 0.25 & 0.35 & 0.45 \\
\hline 15 & $2.52 \mathrm{aA}$ & $2.06 \mathrm{aA}$ & $2.32 \mathrm{aA}$ & $2.56 \mathrm{aA}$ \\
17 & $1.94 \mathrm{aB}$ & $1.58 \mathrm{bB}$ & $1.64 \mathrm{bB}$ & $2.06 \mathrm{aA}$ \\
19 & $1.52 \mathrm{bB}$ & $0.8 \mathrm{cC}$ & $0.8 \mathrm{cC}$ & $0.94 \mathrm{cC}$ \\
$\mathrm{CV} \%$ & 12.45 & 11.32 & 9.45 & 10.67 \\
\hline
\end{tabular}

Means followed by the same uppercase letter between columns and same lowercase letter between lines do not differ significantly $(p<0.05$, Tukey's test).

tion between gamma radiation and the maintenance of postharvest firmness in papaya (Sunrise Solo variety).

The pulp color (Figure 2), no significant differences between gamma radiation doses were found in $\mathrm{L}^{*}, \mathrm{a}^{*}$ or $\mathrm{b}^{*}$ values. Regression analysis revealed reductions in all 3 variables throughout the evaluation period owing to the ripening of the fruits. The $\mathrm{L}^{*}$ value ranges from 0 (black) to
100 (white). The mean $L^{*}$ value in the present study was 67.04 in the beginning of refrigeration and 52.03 at 19 days after placement in the cold chamber, indicating the ripening of the fruit. More positive $\mathrm{a}^{*}$ values correspond to the ripening of the fruit. In the present study, the mean $a^{*}$ value was -13 before placement in the cold chamber and -1.23 at 4 days after removal from the chamber. Positive $b^{*}$ values represent the presence of the yellow color and negative values represent the presence of the blue color. In the present study, there was little variation in these values throughout the evaluation, from 44.61 in the control sample upon placement in the cold chamber to 22.3 at 4 days after removal from the chamber. In coloring of the pulp Allong et al. (2000) evaluated Kent mangoes, and reported reductions in these parameters considering this to be a common process in the ripening of the fruit.

The statistical analysis demonstrated that only the soluble solids and $\mathrm{pH}$ were correlated with time and doses. Compared to the control, treated fruits showed a decrease in the values of soluble solids (Figure 3A). Increasing amounts of soluble solids indicates the point of physiological maturity and hence the sampling point (Assis, 2004). In
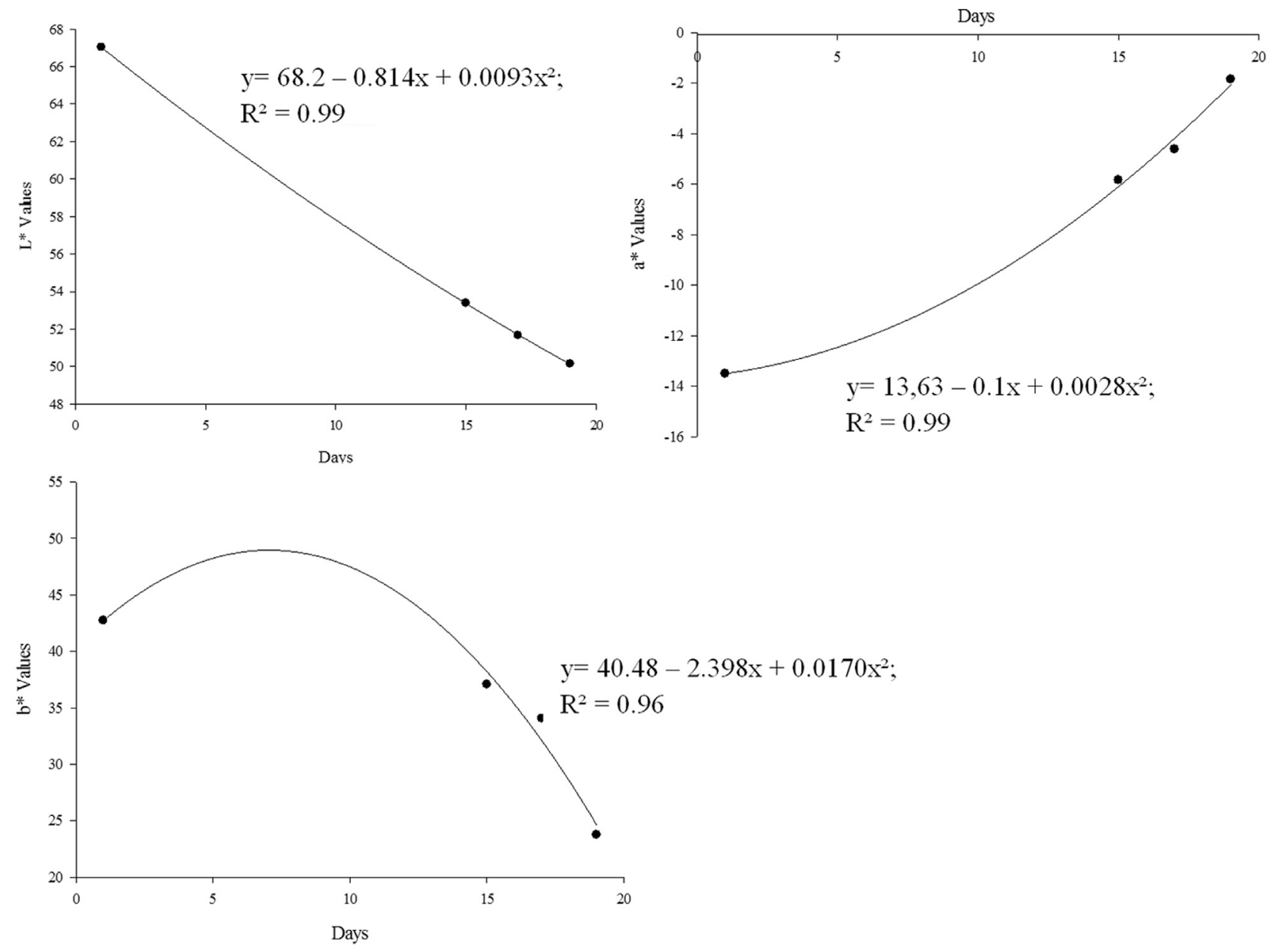

Figure 2 - Regression a function of days of storage for pulp color represented in $\mathrm{L}^{*} ; \mathrm{a}^{*} ; \mathrm{b}^{*}$ values. 

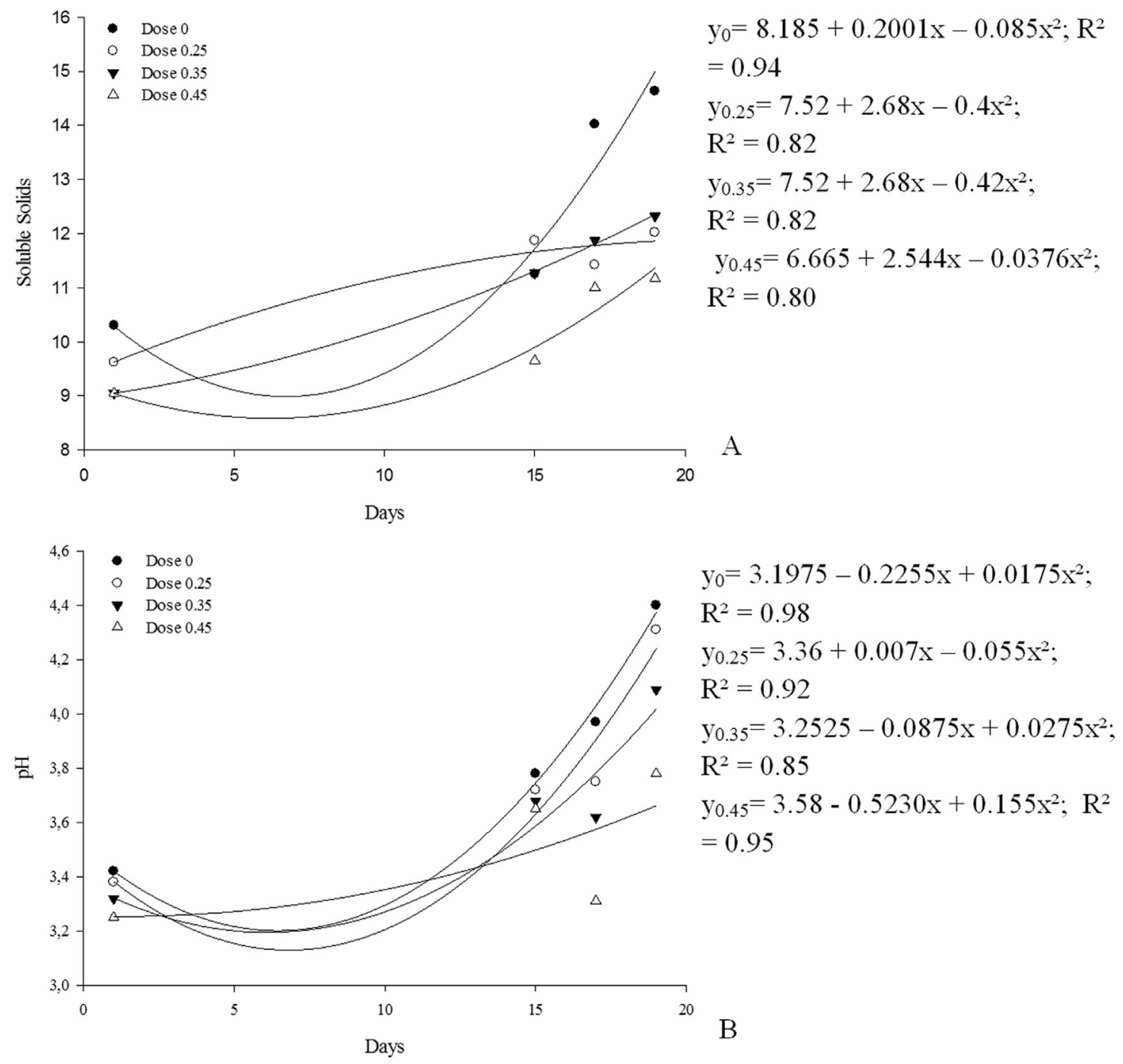

Figure 3 - Interaction between doses of gamma radiation and evaluation days whit regard to chemical characteristics of Tommy Atkins mangos before and after inoculation with $\mathrm{L}$. theobromae and irradiation with doses of $0,0.25,0.35$, and $0.45 \mathrm{kGy}$, followed by refrigerated storage with a PVC wrap at 13 ${ }^{\circ} \mathrm{C}$ and storage without a PVC wrap at $26{ }^{\circ} \mathrm{C}$ with $90 \% \mathrm{RH}$; (A) Total soluble solids ( ${ }^{\circ} \mathrm{Brix}$ ); (B) pH; data transformed into $\mathrm{x}^{1 / 2}$.

a study of the behavior of different mango varieties, Ornelas-Paz et al. (2007) reported that the soluble solids content tends to increase during the ripening process. Thus, the low doses of gamma radiation in the present study did not alter the natural behavior of the mangos during the development. The $\mathrm{pH}$ showed similar behavior between the control and the doses 0.25 and $0.35 \mathrm{kGy}$ only $0.45 \mathrm{kGy}$ dose demonstrated a significant reduction between dose and slightly increased with respect to the valuation days (Figure 3B). The results of $\mathrm{pH}$ were similar to those reported by Thomas et al. (1996), who irradiated mangos with doses of 0.3-1.0 $\mathrm{kGy}$ and found no significant changes in $\mathrm{pH}$ values, even when the ripening of the fruit was slowed. Lima et al. (2001) stressed the importance of evaluating $\mathrm{pH}$ as an intrinsic factor that exerts the greatest selective effect on the microflora likely to develop on fruits and vegetables.
On regard to the ascorbic acid content (Figure 4A), titratable acidity (Figure 4B) or Ratio (Figure 4C), we found no interaction between dose and valuation day and between the different gamma radiation doses. These findings differ from those reported by Youssef et al. (2002), who observed that gamma irradiation of mangos at doses of 0.5 and $2.0 \mathrm{kGy}$ led to an increase in the ascorbic acid content, which may have been influenced by the combination of the radiation and quality of the fruit. In the present study, the ascorbic acid curve demonstrated that the mangos exhibited a reduction in this substance during the ripening process, which is a common finding in most fruits. On regard to titratable acidity, an increase in pulp acidity occurred during the ripening process. With few exceptions, the organic acid content is diminished during maturation owing to either respiration or the conservation of sugars (Chitarra and Chitarra, 2005). 

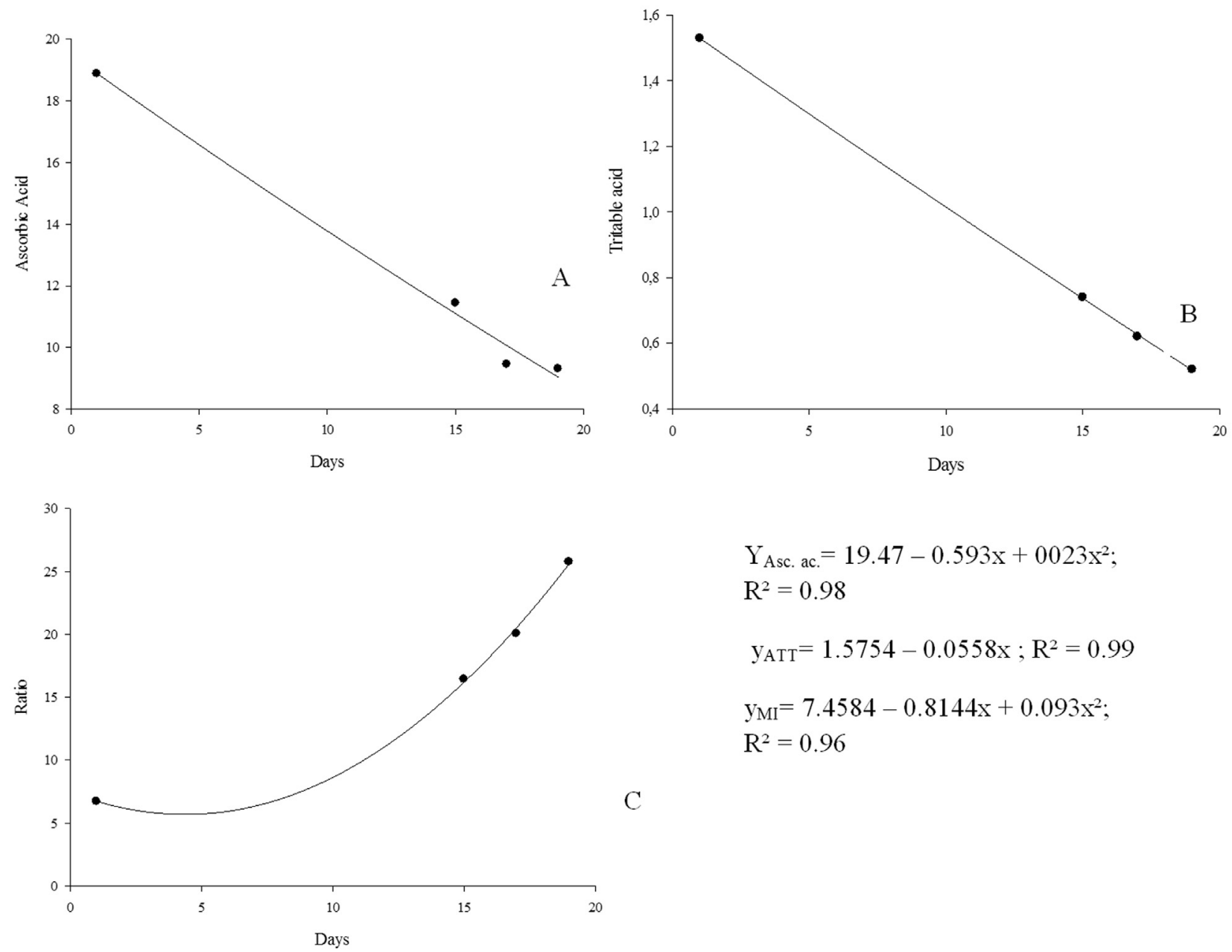

$$
\begin{aligned}
& \mathrm{Y}_{\text {Asc. ac. }}=19.47-0.593 \mathrm{x}+0023 \mathrm{x}^{2} ; \\
& \mathrm{R}^{2}=0.98 \\
& \mathrm{y}_{\mathrm{ATT}}=1.5754-0.0558 \mathrm{x} ; \mathrm{R}^{2}=0.99 \\
& \mathrm{y}_{\mathrm{MI}}=7.4584-0.8144 \mathrm{x}+0.093 \mathrm{x}^{2} ; \\
& \mathrm{R}^{2}=0.96
\end{aligned}
$$

$\mathrm{C}$

Figure 4 - Chemical characteristics before and after inoculation with $\mathrm{L}$. theobromae and irradiation with doses of $0,0.25,0.35$, and $0.45 \mathrm{kGy}$, followed by refrigerated storage with a PVC wrap at $13{ }^{\circ} \mathrm{C}$ and storage without PVC wrap at $26{ }^{\circ} \mathrm{C}$ with $90 \% \mathrm{RH}$; (A) ascorbic acid, (B) titratable acids, (C) Ratio, ascorbic acid data were transformed in $x^{1 / 2}$.

Gamma radiation had no effect on the acidity of the mangos. This finding is similar to that reported by Calore and Vieites (2003), who studied the effect of gamma radiation on the preservation of peaches and found that a dose of $0.1 \mathrm{kGy}$ did not slow the ripening process with regard to acidity. The results of the present study demonstrate that higher doses $(0.24,0.35$ and $0.45 \mathrm{kGy})$ were also not effective.

No difference in Ratio was observed among the different gamma radiation doses, whereas difference was observed during the ripening of the fruit. This index indicates sweetness $v s$. acidity and commercially determines the maturity and quality of the fruit. Camargo et al. (2007) reported a tendency toward an increase in this index after Day 14 with the increase in the temperature, indicating that gamma radiation has little influence over Ratio.

In Conclusion, the use of gamma radiation, even at low doses, can cause a positive effect on disease management during postharvest mango, with little or no influence on fruit quality. IT IS, recommended $0.45 \mathrm{kGy}$ dose by pro- viding a decrease in the development of the pathogen without causing damage properties evaluated for physical and chemical sleeves. The results can be extended to natural infections can predict how the control behaves in the development of the fungus in this study was artificially inoculated.

\section{Acknowledgments}

The authors acknowledge the financial support of the Conselho Nacional de Desenvolvimento Científico e Tecnológico $(\mathrm{CNPq})$ and the Copa Fruit Farm for the donation of mangos.

\section{References}

Allong RD, Wickham LD, Mohammed M (2000) The effect of cultivar, fruit ripeness, storage temperature and duration on quality of fresh-cut mango. Acta Hortic 529:478-494.

Almeida CO, Cardoso, CEL, Santana MA (2005) Comercialização. In: Pereira MEC, Fonseca N, Souza FVD (Eds.) 
Manga: o produtor pergunta, a Embrapa responde. Brasília DF. Embrapa Informação Tecnológica pp. 177-184.

Alves RMV, Sigrist JMM, Padula M (1998) Atmosfera modificada em mangas "Tommy Atkins". Rev Bras Frutic 20:220228.

Assis JIS de (2004) Cultivo da mangueira. Petrolina: Embrapa Semi Árido, 2004. Disponível em:http://sistemasdeproducao.cnptia.embrapa.br/FontesHT ML/Manga/CultivodaMangueira/ colheita.htm > . Acesso em: 25 jan. 2014.

Bernardes-Silva APF, Lajolo FM, Cordenunsi BR (2003) Evolução dos teores de amido e açucares solúveis durante o desenvolvimento e amadurecimento de diferentes cultivares de manga. Ciênc Tecnol Aliment 23:116-120.

Carvalho CRL, Mantovani DMB, Carvalho PRN et al. (1990) Análises químicas de alimentos. Campinas: ITAL 121pp.

Camargo RJ, Tadini CC, Sabato SF (2007) Physical-chemical analyses of irradiated papayas (Carica papaya L.). Radiat Phys Chem 76:1866-1868.

Calore L, Vieites RL (2003) Conservação de pêssegos 'Buiti' por irradiação. Ciênc Tecnol Aliment 23:53-57.

Chitarra MIF, Chitarra AB (2005) Pós-colheita de frutos e hortaliças: fisiologia e manuseio. 2a ed. UFLA, Lavras, 785 pp.

Jerônimo EM, Kanesiro MAB (2000) Efeito da associação de armazenamento sob refrigeração e atmosfera modificada na qualidade de mangas 'Palmer'. Rev Bras Frutic 22:237-243.

Kaferstein FK, Moy GG (1993) Public health aspects of food irradiation. J Public Health Policy 14:149-163.

Lima MAC, Silva AL, Azevedo SSN (2009) Evolução de indicadores do ponto de colheita em manga 'Tommy Atkins' durante o crescimento e a maturação, nas condições do vale de São Francisco. Ciênc Agrotec 33:432-439.

Lima KSC, Grossi JLS, Lima ALS et al. (2001) Efeito da radiação ionizante gama na qualidade pós-colheita de cenouras (Daucus carota L.) cv. Nantes Ciênc Tecnol Aliment 21:202-208.

Morais PLD, Filgueiras HAC, Pinho JLN et al. (2003) Ponto de colheita ideal de mangas 'Tommy Atkins' destinadas ao mercado europeu. Rev Bras Frutic 24:671-675.
Miller WR, McDonald RE (1999) Irradiation, stage of maturity harvest and storage temperature during ripening affect papaya fruit quality. Hort Sci 34:1112-1115.

Nagajata KV (2007) Biochemistry of cashew (Anacardium occidentale L): a review. J Food Sci Technol 44:1-9.

Neves LC, Manzione RL, Vieites RL (2002). Radiação gama na conservação pós-colheita da nectarina (Prunus persica var. nucipersica) frigoconservada. Rev Bras Frutic 24:676-679.

Ohlweiler OA (1980). Química analítica quantitativa 2 ed. Livros Técnicos e Científicos, Rio de Janeiro, 232 pp.

Ornelas-paz JJ, Yahia EM, Gardea-Beja A (2007) Identification and quantificação of xanthophyll esters, carotenes, and tocopherols in the of seven Mexican mango cultivars by liquid chromatography-atmospheric pressure chemical ionization-time-of-flight mass spectrometry. J Agric Food Chem 55:6628-6635.

Pfaffenbach LB, Castro JV de, Carvalho CRL et al. (2003) Efeito da atmosfera modificada e da refrigeração na conservação pós-colheita de manga espada vermelha. Rev Brasil Fruticult 25:410-413.

SIGMAPLOT (2008) For windows, version 11.0. Systat Software, 2008.

Tavares SCCH (2002) Epidemiologia e manejo integrado de Botryodiplodia theobromae -situação atual no Brasil e no mundo. Trop Plant Pathol 27:46-52.

Tavares SCCH, Menezes M, Choudury MM (1991) Infecção de mangueira por Botryodiplodia theobromae, Lat. na região semi-árida de Pernambuco. Rev Bras Frutic 13:163-166.

Thomas P, Bhushan MR, Ramamurthy MS (1996) Comparative studies on the efficacy of gamma irradiation, heat, refrigeration and combined treatments as a quarantine treatment for mango fruit. IAEA - TEC DOC 871.

Thomas P (1986) Radiation preservation of foods of plant origin: III, tropical fruits: bananas mangos and papayas. Crit Rev Food Sci Nutr 23:147-205.

Youssef BM, Asker AA, El-Samahy SK et al. (2002) Combined effect of steaming gamma irradiation on the quality of mango pulp stored at refrigerated temperature. Food Res $35: 1-13$.

Associate Editor: Susana Marta Isay Saad

All the content of the journal, except where otherwise noted, is licensed under a Creative Commons License CC BY-NC. 